\title{
The influence of light quality in the in vitro cultivation of Cattleya crispata (Thunb.) Van den Berg
}

\author{
Denys Matheus Santana Costa SOUZA ${ }^{1}$, Sergio Bruno FERNANDES ${ }^{1}$, Letícia Vaz MOLINARI ${ }^{1}$, \\ Maria Lopes Martins AVELAR ${ }^{1}$, Douglas Santos GONÇALVES ${ }^{1}$, Júlio Cezar Tannure FARIA, \\ Gustavo Leal TEIXEIRA ${ }^{1}$, Gilvano Ebling BRONDANI ${ }^{*}$ \\ ${ }^{1}$ Universidade Federal de Lavras, Lavras, MG, Brasil. \\ *E-mail: gilvano.brondani@ufla.br \\ (Orcid: 0000-0003-4256-7163; 0000-0002-9214-2377; 0000-0002-2543-4628; 0000-0001-6790-685X; \\ 000-0003-2580-8463; 0000-0001-7081-3726; 0000-0001-7293-0790; 0000-0001-8640-5719)
}

\begin{abstract}
Recebido em 01/12/2021; Aceito em 16/12/2021; Publicado em 21/12/2021.
ABSTRACT: Micropropagation technique is a valuable alternative for high quality genetic preservation of endemic species such as the orchid Cattleya crispata from "Campo Rupestre Ferruginoso". This study aims to evaluate the influence of light quality on in vitro multiplication and elongation phases, offering new insights on the limiting factors of $C$. crispata. Seeds extracted from capsules were used for inoculation in the culture medium. Four light sources were evaluated for in vitro culture, namely: fluorescent lamp, white LEDs, red LEDs and red/blue LEDs. Data about the number of shoots, shoot length, shooting vigor and pigment content were assessed at 90 days of in vitro culture. Based on the recorded results, white LEDs are the most suitable ones for in vitro multiplication and elongation phases of $C$. crispata. It offers higher quality for seedling production and increases the chances of genetic conservation of the species.
\end{abstract}

Keywords: 'Campo Rupestre Ferruginoso'; in vitro propagation; wavelength; LEDs.

\section{A qualidade da luminosidade influencia o cultivo in vitro de Cattleya crispata (Thunb.) Van den Berg}

\begin{abstract}
RESUMO: A micropropagação é uma alternativa para a conservação genética de espécies endêmicas do Campo Rupestre Ferruginoso, como a orquídea Cattleya crispata, tendo vantagem a maximização da propagação em elevada qualidade. Para solucionar os fatores limitantes ao cultivo in vitro de $C$. crispata, o presente trabalho teve como objetivo avaliar a influência da qualidade de luz nas fases de multiplicação e alongamento in vitro. Sementes extraídas de cápsulas foram utilizadas para a inoculação em meio de cultura. Avaliaram-se quatro fontes de luz (Lâmpada fluorescente, LEDs branco, LEDs vermelho e LEDs vermelho/azul). Dados referentes ao número, comprimento de brotos, vigor das brotações e conteúdo de pigmentos foram avaliados aos 90 dias de cultivo. Com base nos resultados obtidos, pode-se inferir que LEDs branco é mais adequada para ser utilizada nas fases de multiplicação e alongamento in vitro de C. crispata, sendo uma alternativa para a produção de mudas e conservação genética.
\end{abstract}

Palavras-chave: Campo Rupestre Ferruginoso; propagação in vitro; comprimento de onda; LEDs.

\section{INTRODUCTION}

The Orchidaceae family has many Angiosperms that belong to the Asparagales order, which comprises approximately 24,500 species distributed within 800 genera (CHASE et al., 2015). Brazil holds a great diversity of orchids. It has approximately 239 genera and 2,553 species; 1,636 of them are endemic (Van den Berg, 2008). Some of those are treasured commercial flowers, but the downside is that their culture is based on extractivism, which leads to the destruction of natural habitats and the loss of many individuals (BARROS et al., 2015; ANUCHAI et al., 2017).

The genus Cattleya is native to tropical regions in Central and South America; it encompasses 48 species (Van den BERG, 2014). This genus contains plants that are found in trees from humid forests - from sea level to altitudes up to $1,500 \mathrm{~m}$. Cattleya crispata is a native and endemic species to the Minas Gerais State in Brazil; it is mainly found in the Serra de Ibitipoca region (BARROS et al., 2015), which is a chain of mountains - part of "Campo Rupestre Ferruginoso" formation (Van den BERG, 2014).

However, Cattleya crispata culture remains a challenge, since there are specific demands in the germination, growth, and developmental phases. The population's regeneration is compromised by slow growth and mutualistic interactions with insects and microorganisms, because of pollination or germination (MASSARO et al., 2018). Micropropagation is an alternative to the genetic conservation and multiplication of Cattleya crispata since thousands of plants can be produced from a single propagule. Micropropagation allows genetic gain fixation in clonal populations and maximizes plant highquality propagation within a small physical space and in a short period-of-time, regardless of limiting climatic factors (TRUEMAN et al., 2018; ABIRI et al., 2020).

There is an obvious need for studies on seedling production and understanding the limiting factors of each in 
vitro culture phase of $C$. crispata. Innovations in the culture environment, such as light quality from light emitting diodes (LEDs), stood out among several technologies that have been proposed to improve micropropagation processes (FARIA et al., 2019; RIBEIRO et al., 2019). Studies have indicated that blue $(450-495 \mathrm{~nm})$, red $(620-750 \mathrm{~nm})$, extra red $(750-850 \mathrm{~nm})$ and green lights $(495-570 \mathrm{~nm})$ influence in vitro morphogenesis and plant development (Batista et al., 2018). Micropropagation studies and research on the effects of the different LED wavelengths on the yet non-existing morphogenesis and growth processes have been carried out.

The development of specific micropropagation methods is of paramount importance, given the need for genetic conservation of $C$. crispata species. Thus, the aim of the present study was evaluating the effect of light quality on in vitro multiplication and elongation.

\section{MATERIAL AND METHODS}

\subsection{Study site and experimental material}

Experiments were conducted at the Laboratory of Tissue Culture of the Agriculture Department of the Federal University of Lavras - UFLA, Lavras - MG, Brazil. The material used for the generation of explants resulted from seeds extracted from mature Cattleya crispata capsules, which were provided by the GERDAU Açominas S.A. company, Ouro Branco - MG, Brazil.

\subsection{In vitro establishment}

Seeds were washed in running water and immersed in a solution with $2.4 \mathrm{~g} \mathrm{~L}^{-1}$ of Orthocide $500^{\circledR}$ (Captan $50 \%$ was used as active ingredient) for 15 minutes. Next, they were washed five times in autoclaved deionized water and immersed in $70 \%$ hydroalcoholic solution (v/v) for 20 seconds, under constant stirring, in horizontal laminar flow chamber. Subsequently, seeds were washed five times in autoclaved deionized water and inoculated under aseptic conditions in test tubes $(25 \times 150 \mathrm{~mm})$ added with $10 \mathrm{~mL}$ of culture medium.

The basic culture medium of the experiments was a MS saline formulation (MURASHIGE \& SKOOG 1962) added with $30 \mathrm{~g} \mathrm{~L}^{-1}$ sucrose (Synth Ltda), $6 \mathrm{~g} \mathrm{~L}^{-1}$ agar (Merck S.A.) and $1 \mathrm{~g} \mathrm{~L}^{-1}$ activated charcoal (Merck S.A.). Culture medium $\mathrm{pH}$ was adjusted to $5.8 \pm 0.05$, prior to agar addition. Culture medium autoclaving was carried out at $127^{\circ} \mathrm{C}$ under pressure of $1.5 \mathrm{kgf} \mathrm{cm}^{-2}$, for 20 minutes.

Seeds were kept for 90 days in a growth room at $24 \pm$ $1^{\circ} \mathrm{C}$, under 16-h light photoperiod and irradiance of $40 \mu \mathrm{mol}$ $\mathrm{m}^{-2} \mathrm{~s}^{-1}$ (which was quantified in radiometer, LI-COR ${ }^{\circledR}$, LI$250 \mathrm{~A}$ Light Meter) under cold white fluorescent lamps. Subcultures were set for culture renewal every 30 days.

\subsection{Multiplication}

Four shoots (standardized at $0.5 \mathrm{~cm}$ ) were prepared and inoculated under aseptic conditions in glass flasks $(250 \mathrm{~mL}$ capacity) added with $50 \mathrm{~mL}$ of MS basic culture medium supplemented with $0.5 \mathrm{mg} \mathrm{L}^{-1}$ BAP (6-benzylaminopurine Sigma $\left.{ }^{\circledR}\right), 0.05 \mathrm{mg} \mathrm{L}^{-1}$ ANA ( $\alpha$-naphthalene acetic acid Sigma $\left.{ }^{\circledR}\right), 6 \mathrm{~g} \mathrm{~L}^{-1}$ agar and $1 \mathrm{~g} \mathrm{~L}^{-1}$ activated charcoal after seed germination and in vitro establishment, at 90 days of culture.

The experiment followed a randomized design, under four different light sources: fluorescent lamp - F/L (HO Sylvania T12, 110 W, São Paulo, Brazil), White-LEDs - W/L (SMD 100, 18 W, Vilux ${ }^{\circledR}$, Vitória, ES, Brazil), Red LEDs R/L (LabPARLL-HR / DB-480, 11.6 W, LabLumens ${ }^{\circledR}$,
Carapicuíba, SP, Brazil) and 1:1 red/blue LEDs - RB/L (LabPARLL-HR / DB-480, 11.6 W, LabLumens ${ }^{\circledR}$, Carapicuíba, SP, Brazil), with eight repetitions (composed of four explants, each).

The mean number of shoots per explant $(>0.5 \mathrm{~cm})$, shoots length $(>0.5 \mathrm{~cm})$, vigor based on the scores scale proposed by Souza et al. (2020a) (Figure 1A-C) and the photo-synthetic ink content were assessed at 90 days of culture.

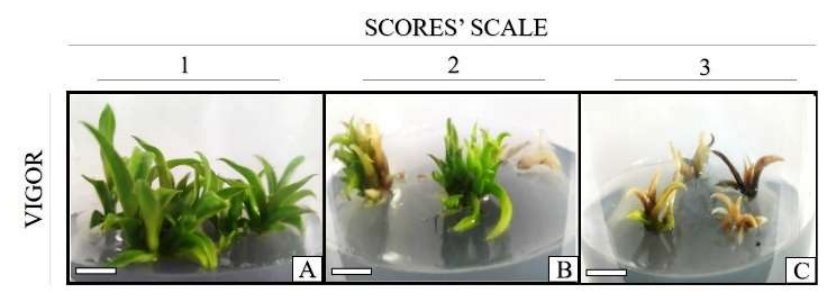

Figure 1. Assessment of vigor, based on the scores scale applied to Cattleya crispata. A. 1 = Excellent: shootings induction by active growth, without apparent nutrition deficit; B. 2 = Good: shootings induction, but reduced leaf size; C. 3 = Low: absence of shootings induction and $/$ or senescence and death. Bars $=1.0 \mathrm{~cm}$.

Figure 1. Avaliação do vigor de acordo com a escala de notas em Cattleya crispata. A. 1 = Ótimo: indução de brotações com crescimento ativo, sem deficiência nutricional aparente; B. 2 = Bom: indução de brotações, porém com folhas de tamanho reduzido; C. 3 = Baixo: ausência de indução das brotações e/ou senescência e morte. Barras $=1,0 \mathrm{~cm}$.

\subsection{Elongation}

Shoots produced in the in vitro multiplication phase were prepared; four shoots (standardized at $0.5 \mathrm{~cm}$ ) were isolated and inoculated (under aseptic conditions) in glass flasks (250 $\mathrm{mL}$ capacity). Each flask was added with $50 \mathrm{~mL}$ of MS culture medium, $30 \mathrm{~g} \mathrm{~L}^{-1}$ sucrose, $6 \mathrm{~g} \mathrm{~L}^{-1}$ agar $1 \mathrm{~g} \mathrm{~L}^{-1}$ activated charcoal, $0.05 \mathrm{mg} \mathrm{L}^{-1} \mathrm{BAP}$ and $0.5 \mathrm{mg} \mathrm{L}^{-1}$ indole-3-butyric acid (AIB) $\left(\right.$ Sigma $\left.^{\circledR}\right)$.

The experiment followed a randomized design, under four different light sources: Fluorescent lamp F/L, LED lamp white $\mathrm{W} / \mathrm{L}$, LED lamp red $\mathrm{R} / \mathrm{L}$ and LED lamp red/blue-RB/L 1:1, with eight repetitions (composed of four explants, each).

Data about the mean number of shoots per explant $(>$ $0.5 \mathrm{~cm})$, shoot length $(>0.5 \mathrm{~cm})$, vigor based on the scores scale and photo-synthetic ink content were collected at 90 days of culture.

\subsection{Quality of light}

A Spectrum radiometer (Ocean Optics Spectra-Suite) was used for the analyzes of variations in the absolute irradiance $\left(\mu \mathrm{W} \mathrm{cm} \mathrm{cm}^{-2} \mathrm{~nm}^{-1}\right)$ and light wavelength $(\mathrm{nm})$ of different lamp types during the in vitro multiplication and elongation phases. It was done to plot the graphics of different light spectra (Figure 2).

\subsection{Photosynthetic pigment analysis}

Leaf discs (25 mg of leaf fresh matter) were sampled from shooting for in vitro multiplication and elongation assays, after 90 days of culture, under different light sources. Samples were inoculated with $5 \mathrm{~mL}$ of DMSO solution (Sigma Aldrich $($ ) and stored for 48 hours in the dark (LICHTENTHALER, 1987). Sample absorbance was determined in triplicate, in $10 \mathrm{~mm}$ optical path quartz cuvette, in Genesys 10UV spectrophotometer (ThermoScientific ${ }^{\circledR}$, EUA). 

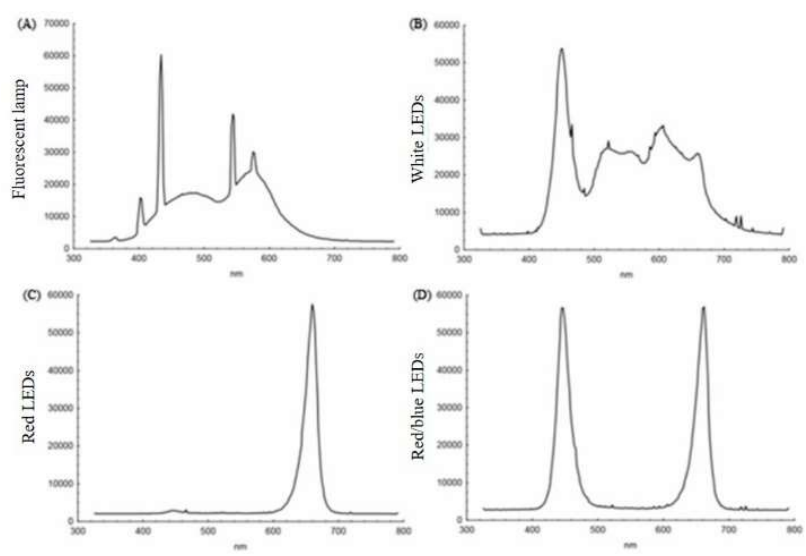

Figure 2. Variations in absolute $\left(\mu \mathrm{W} \mathrm{cm} \mathrm{cm}^{-2} \mathrm{~nm}^{-1}\right)$ and light wavelength $(\mathrm{nm})$ of different lamp types during in vitro culture of Cattley a crispata. A. Fluorescent lamp; B. White LEDs; C. Red LEDs; D. Red/blue LEDs 1:1.

Figure 2. Variações da irradiância absoluta $\left(\mu \mathrm{W} \mathrm{cm}^{-2} \mathrm{~nm}^{-1}\right)$ e do comprimento de onda (nm) de luz emitido pelas diferentes lâmpadas durante o cultivo in vitro de Cattleya crispata. A. Lâmpada fluorescente; B. LEDs branco; C. LEDs vermelho; D. LEDs vermelho/azul 1:1.

\subsection{Data analysis}

The analyses were carried out in R Core Team software, 2018, with the aid of the ExpDes Package, version 1.1.2 (FERREIRA et al., 2013). Data were subjected to analysis of variance (ANOVA) with Tukey test at 5\% significance level.

\section{RESULTS}

\subsection{Quality of light on in vitro multiplication}

Different qualities of light influenced the number of shoots per explant and led to the highest means under sources W/L (4.0 shoots) and F/L (3.7 shoots); results were statistically different $(\phi<0.05)$ under sources R/L and RB/L (Figure 3A). Shoots length presented similar behavior: the best results were recorded for sources $\mathrm{W} / \mathrm{L}(2.74 \mathrm{~cm}$, on average) and $\mathrm{F} / \mathrm{L}(2.44 \mathrm{~cm}$, on average), which recorded values different from those recorded under sources $\mathrm{R} / \mathrm{L}$ and $\mathrm{RB} / \mathrm{L}$ (Figure 3B).
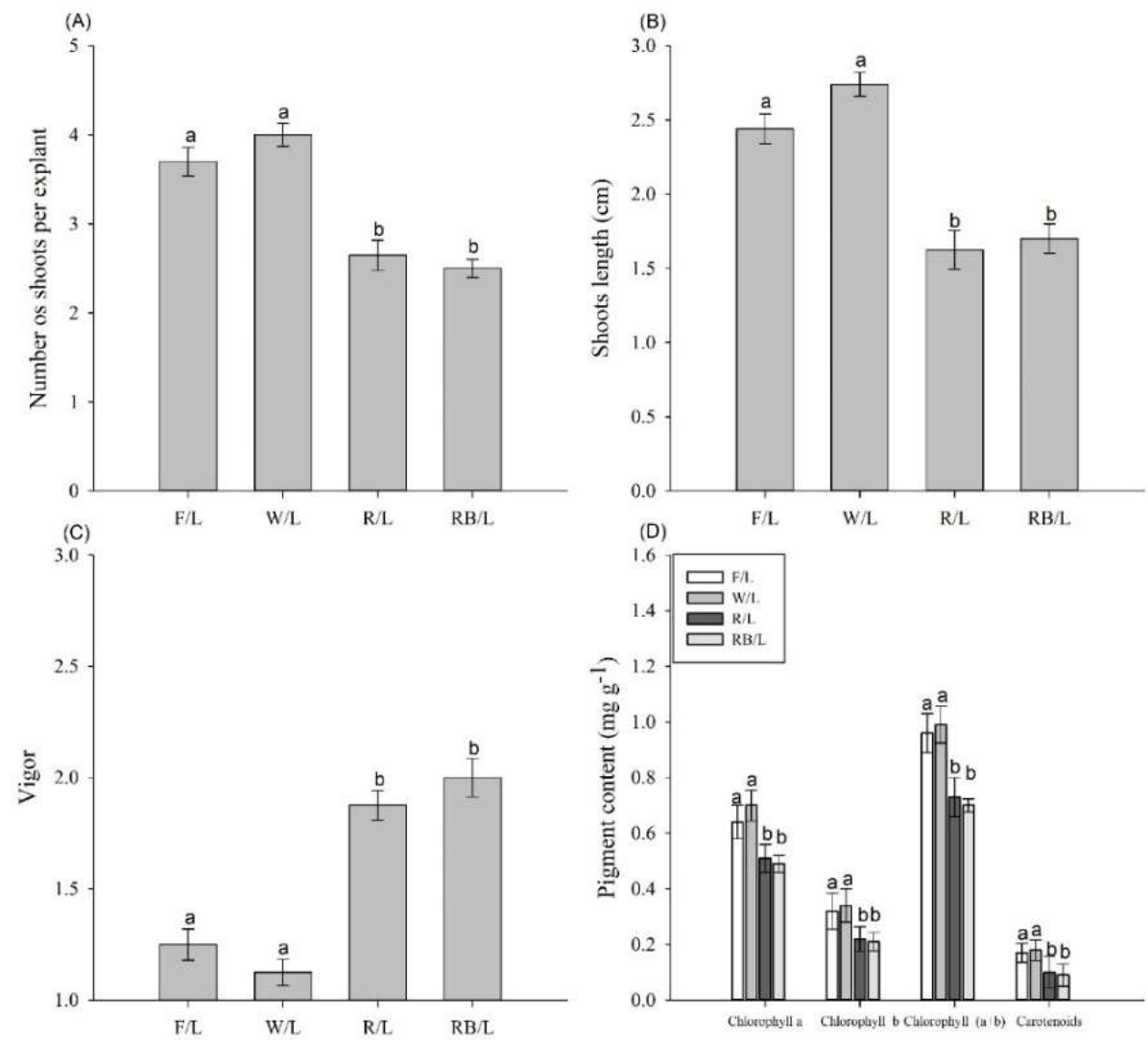

Figure 3. Features observed at 90 days of in vitro multiplication phase of Cattleya crispata related to different qualities of light (Fluorescent lamp (F/L), white LEDs (W/L), red LEDs (R/L), and red/blue LEDs (RB/L)). A. Mean number of shoots per explant; B. Mean shoots length; C. Vigor; D. Mean pigment content. ${ }^{*}$ Means followed by the same letter did not differ from each other in the Tukey test at $5 \%$ significance level. Bars represent sample standard deviation.

Figure 3. Características observadas aos 90 dias durante a fase de multiplicação in vitro de Cattleya crispata em função das diferentes qualidades de luz (Lâmpada fluorescente (F/L), LEDs branco (W/L), LEDs vermelho (R/L) e LEDs vermelho/azul (RB/L). A. Número médio de brotos por explante; B. Comprimento médio de broto; C. Vigor; D. Conteúdo médio de pigmentos. *Médias seguidas de uma mesma letra não diferem entre si, pelo teste de Tukey à 5\% de significância. Barras representam o desvio padrão amostral.

W/L presented the lowest means of explant vigor (1.12) based on the scores scale; this result was significantly different $(\phi<0.05)$ under light sources $\mathrm{R} / \mathrm{L}$ and $\mathrm{RB} / \mathrm{L}$ (Figure 3C). Regarding the content of photosynthetic pigments, the amount of chlorophyll $a, b, a+b$ and carotenoids were influenced by different light qualities
(Figure 3D). The results showed that the light sources W / L and F / L had the highest levels of photosynthetic ink.

\subsection{Quality of light on in vitro elongation}

A difference in responses between light sources and the growth pattern of C. crispata plants in the in vitro multiplication 
and elongation phases at 90 days of culture (Figure 5) was observed. Based on the quality of the analyzed lights, F/L stood out for producing the largest number of shoots $(3.68$ shoots, on average, Figure 4A), which was statistically different from that recorded for the other treatments $(\phi<$ $0.05)$. However, the lowest shoots production mean was observed under light source RB/L (2.0 shoots).

For the shoots length, the best results of were under light source W/L (4.43 cm, on average) (Figure 4B). Regarding explant vigor, the lowest mean values based on the score scale were observed under W/L (1.12) (Figure 4C), which led to tissue growth due to lack of nutritional deficit.

The best ink content results were those recorded under light source W/L (Figure 4D); this outcome evidenced the importance of using light-emitting diodes (LEDs) that present greater wavelength specificities.

Based on the evaluated characteristics, it was possible to observe difference in the growth pattern of $C$. crispata explants through different light qualities used for in vitro multiplication and elongation at 90 days (Figure 5).
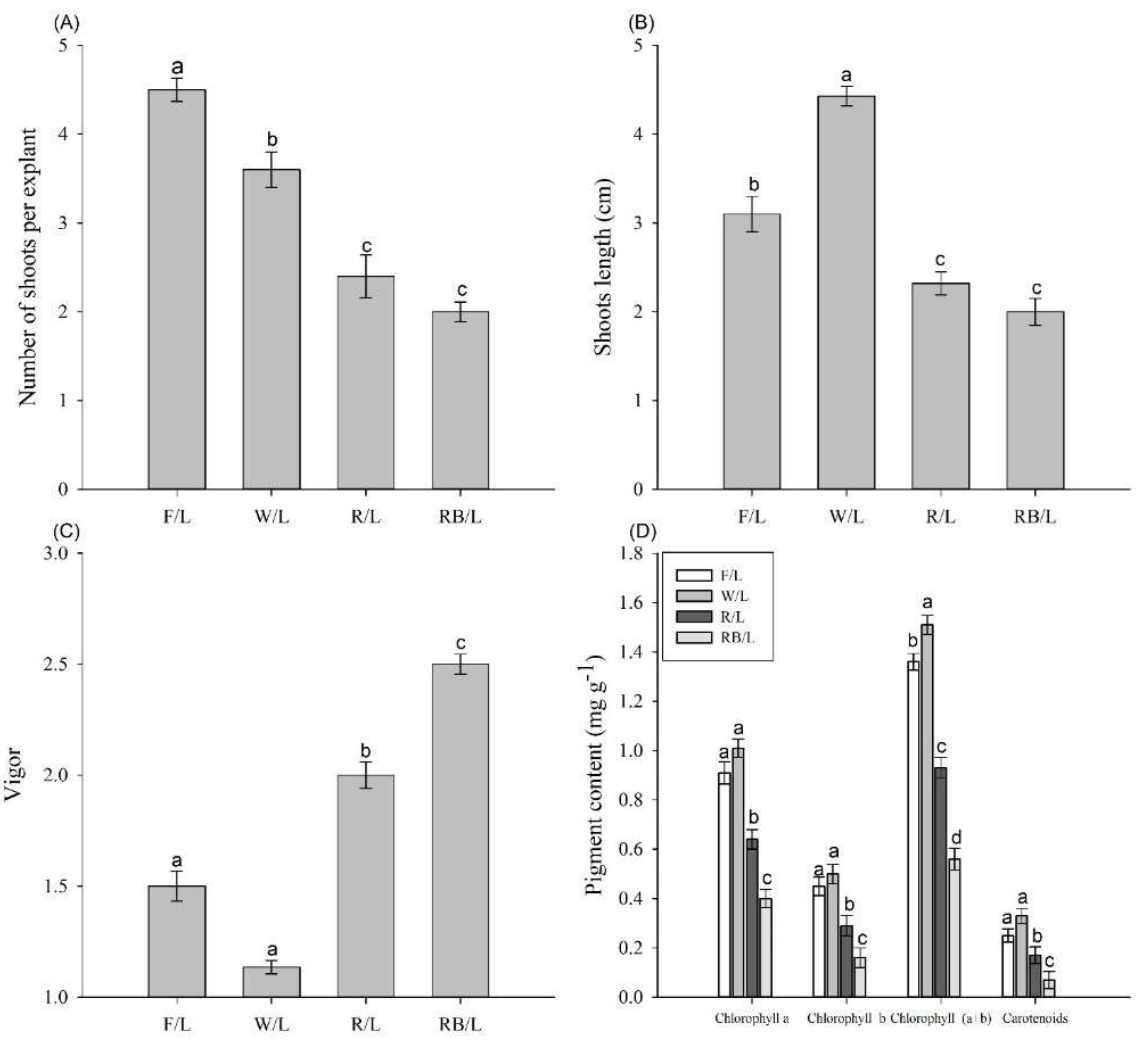

Figure 4. Features observed at 90 days of in vitro elongation phase of Cattleya crispata due to different qualities of light (F/L) fluorescent lamp, white LEDs (W/L), red LEDs (R/L), and red/ blue LEDs (RB/L)). A. Mean number of shoots per explant; (B) Mean shoots length; C. Vigor; D. Mean ink content. *Means followed by the same letter did not differ from each other in the Tukey test at $5 \%$ significance level. Bars represent the sample standard deviation.

Figure 4. Características observadas aos 90 dias durante a fase de alongamento in vitro de Cattleya crispata em função das diferentes qualidades de luz (Lâmpada fluorescente (F/L), LEDs branco (W/L), LEDs vermelho (R/L) e LEDs vermelho/azul (RB/L). A. Número médio de brotos por explante; (B) Comprimento médio das brotações; C. Vigor; D. Conteúdo médio de pigmentos. * Médias seguidas de uma mesma letra não diferem entre si, pelo teste de Tukey à $5 \%$ de significância. Barras representam o desvio padrão amostral.

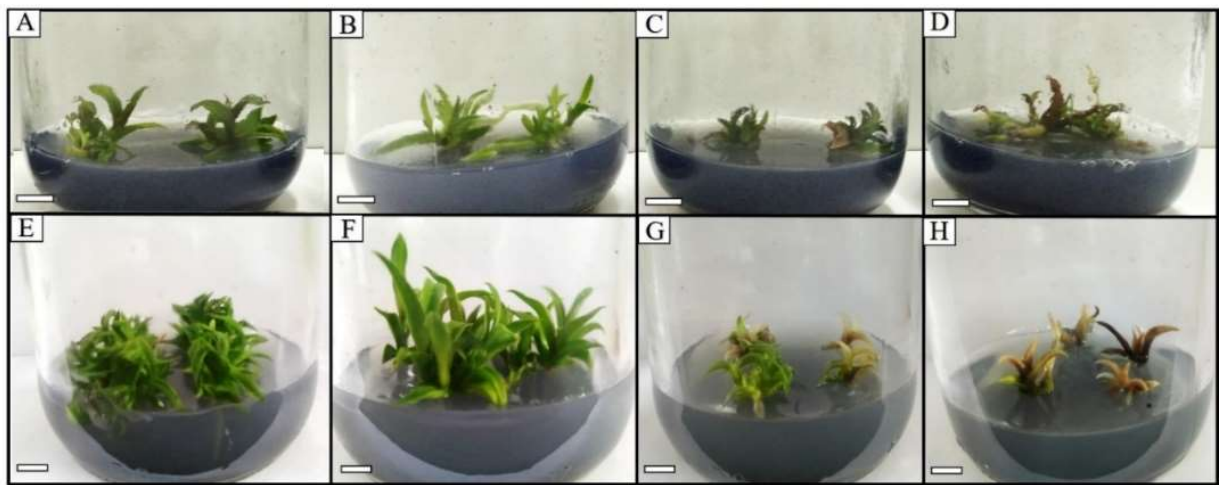

Figure 5. Explants of orchids from the species Cattleya crispata under different qualities of light at 90 days of culture. A-D. In vitro multiplication; E-H. In vitro elongation; $\mathbf{A}$ and E. Fluorescent lamp; $\mathbf{B}$ and F. White LEDs; $\mathbf{C}$ and $\mathbf{G}$. Red LEDs; $\mathbf{D}$ and $\mathbf{H}$. red/blue LEDs. Bars $=1.0 \mathrm{~cm}$.

Figure 5. Explantes da orquídea Cattleya crispata em diferentes qualidades de luz, aos 90 dias de cultivo. A-D. Multiplicação in vitro; E-H. Alongamento in vitro; A e E. Lâmpada fluorescente; $\mathbf{B}$ e F. LEDs branco; $\mathbf{C}$ e $\mathbf{G}$. LEDs vermelho; $\mathbf{D}$ e $\mathbf{H}$. LEDs vermelho/azul. Barra $=$ $1,0 \mathrm{~cm}$. 


\section{DISCUSSION}

\subsection{Quality of light on in vitro multiplication}

The improvement of protocols for in vitro multiplication that influences the development of micropropagation, were studied with the attempt to establish cultivation conditions that can maximize the production of clonal seedlings on a large scale. The results of the morphological characteristics evaluated with the orchid $C$. crispata, provided the optimization of the in vitro multiplication phase, through the use of light quality.

Treatment with white LED light quality provided the best results for number of shoots per explant, shoot length and vigor after 90 days of cultivation. Data in the literature corroborated the current results, since the use of white LEDs on the orchid species Microlaelia lundii (FAVETA et al., 2017) and Corymbia torelliana $\times$ C. citriodora (SOUZA et al., 2020b) favored the largest number of and longest shoots. On the other hand, the smallest number and shortest length of explants from Ajuga multiflora were recorded under red/blue LED light (BYOUNG; IYYAKKANNU, 2018).

These results are also in line with those found by Souza et al. (2020b), who observed adequate explant vigor of Corymbia torelliana $\times$ C. citriodora. According to Abiri et al. (2020), the success of the multiplication phase requires explants for the emission of shoots free from contamination and with adequate vegetative vigor.

Light quality control on in vitro culture under LED light sources is essential for photosynthetic rate optimization, a fact that contributes to the growth and increase of shoots production (SILVA et al., 2017). However, light can also influence the concentration of growth regulators by acting as a morphogenic sign to shoots proliferation during the in vitro multiplication. The initial phases in the light-induced signaling involve the activation of cytokinins (ROMAN et al., 2016), which may be beneficial for shoots production.

As for the content of photosynthetic pigments (chlorophyll $a, b a+b$ and carotenoids), the highest values were observed in light of white LEDs. Similar results were observed in Bixa orellana cultivar UESB74 under white LEDs (FARIA et al., 2019). The biosynthesis of chlorophyll $a, b$ and of carotenoids was influenced by the quality and intensity of the emitted light. The photosynthetic process presented the highest efficiency, mainly when the light source with the greatest wavelength specificity was adopted (GUPTA; KARMAKAR, 2017).

\subsection{Quality of light on in vitro elongation}

The specificity of the light quality fluorescent and white provided the best results for the morphological characteristics studied in the in vitro elongation. Similar results were observed when fluorescent light was the light source provided to Abies borisii-regis explants (SMIRNAKOU et al., 2016).

In contrast, it was observed that the use of light quality red and red blue is inadequate. The blue region of the light spectrum (450 to $500 \mathrm{~nm}$ ) can act in growth and productivity inhibition (Abiri et al., 2020).

Wavelengths in LED light sources have a specific action in plants, they influence different factors in plants' photosynthetic processes, morphogenesis, and physiological processes (HE et al., 2017). LED light sources can be used separately, or in combination, for the optimization of morphophysiological processes (SHENGXIN et al., 2016).
However, it is important to highlight that light wavelength has varying responses according to the genotype (MIRANDA et al., 2020); therefore, adjustments are necessary for each species and/or genotype.

As for the content of photosynthetic pigments, the highest values were also observed for fluorescent light sources and white LEDs. Ink content in Fagopyrum tataricum explants exposed to white LED was higher than that recorded for plants treated with blue and red LEDs (TUAN et al. 2013).

LEDs performance has increased the amount of chlorophyll and carotenoids and the photosynthetic growth ability of certain species (SOUZA et al. 2020a). Carotenoids play an important role in photosynthesis since they protect the photosystem from photo-oxidation. However, the effects of different light wavelengths on carotenoid biosynthesis may depend on the assessed tissues and plants (TIAN et al. 2019).

Given the above, it is important to note that light emitting diodes (LEDs) are alternative light sources, given their wavelength specificities, a moderate amount of thermal emission, little degradation and long service life. These characteristics favor in vitro culture and reduce costs compared to fluorescent lamps (BUGBEE, 2016). Therefore, LEDs are an excellent alternative in plant tissue culture.

\section{CONCLUSION}

LEDs presented the best results for in vitro multiplication and elongation of Catlleya crispata also leading to greater vigor, longer shoots, a larger mean number of shoots per explant, and higher photosynthetic ink content. This finding turns LED into an alternative to seedling production and the genetic conservation of the species.

\section{ACKNOWLEDGEMNTS}

We are grateful to "Fundação de Amparo à Pesquisa do Estado de Minas Gerais (FAPEMIG)" for the granted scholarships. The present study was carried out with the support of "Conselho Nacional de Desenvolvimento Científico e Tecnológico (CNPq)" and "Coordenação de Aperfeiçoamento de Pessoal de Nível Superior (CAPES)". We also thank GERDAU Açominas S. A.

\section{REFERENCES}

ABIRI, R.; ATABAKI, N.; ABDUL-HAMID, H.; SANUSI, R.; SHUKOR, N. A. A.; SHAHARUDDIN, N. A.; AHMAD, S. A.; MALIK, S. The prospect of physiological events associated with the micropropagation of Eucalyptus sp. Forests, v. 11(11), 1211, 2020. DOI: https://doi.org/10.3390/f11111211

ANUCHAI, V.; HSTEH, C. H. Effect of change in light quality on physiological transformation of in vitro Phalaenopsis 'Fortune Saltzman' seedlings during the growth period. Horticultural Science, v. 86, p. 1-8, 2017. DOI: https://doi.org/10.3389/fpls.2019.01258

BARROS, F.; VINHOS, F.; RODRIGUES, V. T.; BARBERENA, F. F. V. A.; FRAGA, C. N.; PESSOA, E. M.; FORSTER, W.; MENINI NETO, L.; FURTADO, S. G.; NARDY, C.; AZEVEDO, C. O.; GUIMARÃES, L.R.S. Orchidaceae na lista de espécies da flora do Brasil, Jardim Botânico do Rio de Janeiro. Disponível em:

http://floradobrasil.jbrj.gov.br/jabot/floradobrasil/FB1 79. Acesso em 10 fev. 2021. 
BATISTA, D. S.; FELIPE, S. H. S.; SILVA, T. D.; CASTRO, K. M. D.; MAMEDES-RODRIGUES, T. C.; MIRANDA, N. A.; RÍOS-RÍOS, A. M.; FARIA, D. V.; FORTINI, E. A.; CHAGAS, K.; TORRES-SILVA, G.; XAVIER, A.; ARENCIBIA, A. D.; OTONI, W. C. Light quality in plant tissue culture: does it matter?. In Vitro Cellular and Developmental Biology - Plant, v. 54, p. 195-215, 2018. DOI: https://doi.org/10.1007/s11627018-9902-5

BUGBEE, B. Toward an optimal spectral quality for plant growth and development: the importance of irradiation capture. Acta Horticulturae, v. 1134, p. 1-12, 2016. https://doi.org/10.17660/ActaHortic.2016.1134.1

BYOUNG, R. J.; IYYAKKANNU, S. Impact of light quality and sucrose on adventitious shoot regeneration and bioactive compound accumulation in Ajuga multiflora Bunge. Scientia Horticulturae, v. 236, p. 222-228, 2018. DOI: https://doi.org/10.1016/j.scienta.2018.03.056

CHASE, M. W.; CAMERON, K. M.; FREUDENSTEIN, J. V.; PRIDGEON, A. M.; SALAZAR, G.; VAN DEN BERG, C.; SCHUITEMAN, A. An update classification of Orchidaceae. Botanical Journal of the Linnean Society, v. 177, p. 151-174, 2015. DOI: https://doi.org/10.1111/boj.12234

FAN, X. X.; XU, Z. G.; LIU, X. Y.; TANG, C. M.; WANG, L. W.; HAN, X. L. Effects of light intensity on the growth and leaf development of young tomato plants grown under a combination of red and blue light. Scientia Horticulturae, v. 153, p. 50-55, 2013. DOI: https://doi.org/10.1016/j.scienta.2013.01.017

FARIA, D. V.; CORREIA, L. N. F.; SOUZA, M. V. C.; RÍOS, A. M. R.; VITAL, C. E.; BATISTA, D. S.; COSTA, M. G. C; OTONI, W. C. Irradiance and light quality affect two annatto (Bixa orellana L.) cultivars with contrasting bixin production. Journal of Photochemistry \& Photobiology, B: Biology, v. 19, p. 1011-1344, 2019. DOI: https://doi.org/10.1016/j.jphotobiol.2019.111549

FAVETTA, V.; COLOMBO, R. C.; JÚNIOR, J. F. M.; FARIA, R. T. Light sources and culture media in the in vitro growth of the Brazilian orchid Microlaelia lundii. Ciências Agrárias, v. 38, p. 1775-1784, 2017. DOI: https://doi.org/10.5433/1679-0359.2017v38n4p1775

FERREIRA, E. B.; CAVALCANTI, P. P.; NOGUEIRA, D. A. ExpDes: Experimental Designs package. $\mathbf{R}$ package version 1.1.2, 2013.

GUPTA, S. D.; KARMAKAR, A. Machine vision based evaluation of impact of light emitting diodes (LEDs) on shoot regeneration and the effect of spectral quality on phenolic content and antioxidant capacity in Swertia chirata. Journal of Photochemistry and Photobiology B, v. 174 , p. 162-172, 2017. DOI: https://doi.org/10.1016/j.jphotobiol.2017.07.029

HE, J., QIN, L.; CHONG, E. L. C.; CHOONG, T. W.; LEE, S. K. Plant growth and photosynthetic characteristics of Mesembryanthemum crystallinum grown aeroponically under different blue- and red-LEDs. Frontiers in Plant Science, v. 8, p. 361-372, 2017. DOI: https://doi.org/ 10.3389 /fpls.2017.00361

LICHTENTHALER, H. K. Chlorophylls and carotenoids: pigments of photosynthetic biomembranes. In: PACKER, L.; DOUCE, R. (Eds). Methods in enzimology, London: Academic, 1962. 381p.
MASSARO, R.; FADIN, D. A.; MORAES, C. P. M.; VIEIRA, A. S.; MARTELINE, M. A. Light quality in vitro growth and acclimatization of two varieties of Phalaenopsis amabilis alba Blume (Orchidaceae). Iheringia: Série Botânica, v. 73, p. 208-215, 2018. DOI: https://doi.org/10.21826/2446-8231201873113

MIRANDA, N. A.; XAVIER, A.; OTONI, W. C.; GALLO, R.; GATTI, K. C.; MOURA, L. C.; SOUZA, D. M. S. C.; MAGGIONI, J. H.; SANTOS, S. S. O. Quality and intensity of light in the in vitro development of microstumps of Eucalyptus urophylla in a photoautotrophic system. Forest Science, v. 66, p. 754-760, 2020. https://doi.org/ 10.1093/forsci/fxaa027

MURASHIGE, T.; SKOOG, F. A revised medium for rapid growth and bioassays with tobacco tissue cultures. Physiologia Plantarum, v. 15, p. 473-497, 1962.

OUZOUNIS, E.; ROSENQVIST, C. O.; OTTOSEN, C.-O. Spectral effects of artificial light on plant physiology and secondary metabolism: a review. Hortscience, v. 50, p. 1128-1135, 2015.

DOI: https://doi.org/10.21273/HORTSCI.50.8.1128

RAMÍREZ-MOSQUEDA, M. A.; IGLESIAS-ANDREU, L. G.; BAUTISTA-AGUILAR, J. R. The effect of light quality on growth and development of in vitro plantlet of Stevia rebaudiana Bertoni. Sugar Tech, v. 19, p. 331-336, 2017. DOI: https://doi.org/10.1007/s12355-016-0459-5 RIBEIRO, L. M.; SORGATO, J C.; SCALON, S. P. Q.; SOARES, J. S.; RIBEIRO, I. S. Influência da luz, ventilação natural e tamanho do frasco no crescimento e desenvolvimento de denphal (Orchidaceae). Revista Brasileira de Ciências Agrárias, v. 14, p. 1-7, 2019. DOI: https://doi.org/10.5039/agraria.v14i3a5957

ROMAN, H.; GIRAULT, T.; BARBIER, F.; PÉRON, T.; BROUARD, N.; PĚNČÍK, A.; NOVÁK, O.; VIAN, A., SAKR, S.; LOTHIER, J.; LE GOURRIEREC, J. Cytokinins are initial targets of light in the control of bud outgrowth. Plant Physiology, v. 172, p. 489-509, 2016. DOI: https://doi.org/10.1104/pp.16.00530

SHENGXIN, C.; LI, C.; XUYANG, Y.; SONG, C. Morphological, photosynthetic, and physiological responses of rapeseed leaf to different combinations of red and blue lights at the rosette stage. Frontiers in Plant Science, v. 7, p. 1-11, 2016. DOI: https://doi.org/ 10.3389/fpls.2016.01144

SILVA, S. T.; BERTOLUCCI, S. K. V.; DA CUNHA, S. H. B.; LAZZARINI, L. E. S.; TAVARES, M. C.; PINTO, J. E. B. P. Effect of light and natural ventilation systems on the growth parameters and carvacrol content in the in vitro cultures of Plectranthus amboinicus (Lour.) Spreng. Plant Cell, Tissue and Organ Culture, v. 129, p. 501-510, 2017. DOI: https://doi.org/10.1007/s11240-017-1195-6

SINGH, A. S.; JONES, A. M. P.; SHUKLA, M. R.; SAXENA, P. K. High light intensity stress as the limiting factor in micropropagation of sugar maple (Acer saccharum marsh.). Plant Cell, Tissue Organ Culture, v. 129, p. 209-221, 2017. DOI: https://doi.org/10.1007/s11240017-1170-2

SMIRNAKOU, S.; OUZOUNIS, T.; RADOGLOU, K. Effects of continuous spectrum LEDs used in indoor cultivation of two coniferous species Pinus sylvestris L. and Abies borisii-regis Mattf. Scandinavian Journal of Forest Research, v. 31, p. 115-122, 2016. DOI: https://doi.org/10.1080/02827581.2016.1227470 
SOUZA, D. M. S. C. S.; FERNANDES, S. B.; AVELAR, M. L. M.; FRADE, S. R. P.; MOLINARI, L. V.; GONÇALVES, D. S.; PINTO, J. E. B. P.; BRONDANI, G. E. Light quality in micropropagation of Eucalyptus grandis $\times$ Eucalyptus urophylla, Scientia Forestalis, v. 48, p. 1-13, 2020a. DOI: https://doi.org/10.18671/scifor.v48n127.03

SOUZA, D. M. S. C.; XAVIER, A.; MIRANDA, N. A.; GALLO, R.; OTONI, W. C. Light quality, 6benzyladenine and number of subcultives for in vitro multiplication of hybrid clones of Corymbia. Scientia Forestalis, v. 48, p. 1-10, 2020b. DOI: https://doi.org/10.18671/scifor.v48n128.03

TRUEMAN, S. J.; HUNG, C. D.; WENDLING, I. Tissue culture of Corymbia and Eucalyptus. Forests, v. 9, p. 1-42, 2018.

DOI: https://doi.org/https://doi.org/10.3390/f9020084

Van den BERG, C. Reaching a compromise between conflicting nuclear and plastid phylogenetic trees: a new classification for the genus Cattleya (Epidendreae; Epidendroideae; Orchidaceae). Phytotaxa, v. 186, p. 75-86, 2014.

DOI:

http://dx.doi.org/10.11646/phytotaxa.186.2.2 